\title{
Targeting Cancer Stem Cells-A Renewed Therapeutic Paradigm
}

\author{
Catherine L Amey ${ }^{1}$ and Antoine E Karnoub²
}

1. Touch Medical Media, Goring-On-Thames, UK; 2. Department of Pathology, Beth Israel Deaconess Cancer Center and Harvard Medical School, Boston, Massachusetts, US; Harvard Stem Cell Institute, Cambridge, Massachusetts, US; Broad Institute of MIT and Harvard, Cambridge, Massachusetts, US in cancer patients. Better understanding of how cancer cells circumvent therapeutic insults and how disseminated cancer clones generate life-threatening metastases would therefore be paramount to the development of effective therapeutic approaches for clinical management of malignant disease. Mounting reports over the past two decades have provided evidence for the existence of a minor population of highly malignant cells within liquid and solid tumors, which are capable of self-renewing and of regenerating secondary growths with the heterogeneity of the primary tumors from which they derive. These cells, called tumor-initiating cells or cancer stem cells (CSCs) exhibit increased resistance to standard radio- and chemotherapies and appear to have mechanisms that enable them to evade immune surveillance. CSCs are therefore considered to be responsible for systemic residual disease after cancer therapy, as well as for disease relapse. How CSCs develop, the nature of the interactions they establish with their microenvironment, their phenotypic and functional characteristics, as well as their molecular dependencies have all taken center stage in cancer therapy. Indeed, improved understanding of CSC biology is critical to the development of important CSC-based anti-neoplastic approaches that have the potential to radically improve cancer management. Here, we summarize some of the most pertinent elements regarding CSC development and properties, and highlight some of the clinical modalities in current development as anti-CSC therapeutics.

\section{Keywords}

Cancer biomarker, cancer stem cell, tumor-initiating cell, microenvironment, signaling pathway, targeted therapy, radioresistance, chemoresistance

Disclosure: Antoine E Karnoub has nothing to declare in relation to this article. Catherine L Amey is an employee of Touch Medical Media, Goring-On-Thames, UK.

Authorship: All named authors meet the International Committee of Medical Journal Editors (ICMJE) criteria for authorship of this manuscript, take responsibility for the integrity of the work as a whole, and have given final approval to the version to be published.

open Access: This article is published under the Creative Commons Attribution Noncommercial License, which permits any noncommercial use, distribution, adaptation, and reproduction provided the original author(s) and source are given appropriate credit.

Received: February 22, 2017

Accepted: April 20, 2017

Citation: Oncology \& Hematology Review, 2017;13(1):45-55

Corresponding Author: Antoine E Karnoub, Center for Life Science 0634, 3 Blackfan Circle, Boston, MA 02215, US E: akarnoub@bidmc.harvard.edu

Support: The publication of this article was supported by Boston Biomedical, who was given the opportunity to review the article for scientific accuracy before submission. Any resulting changes were made at the authors' discretion.
Despite substantial advances in cancer diagnosis and treatment, the long-term survival rate for many cancer patients remains dismal. ${ }^{1}$ More than $90 \%$ of cancer-related mortality is ascribed to disease resurgence months or years after adjuvant therapy, either in the form of local recurrence or in the form of metastatic spread, which are typically refractory to existing treatment modalities (see Table 1), ${ }^{1,2}$ Novel anti-neoplastic therapeutic approaches aimed at eradicating residual relapsing disease are therefore sorely needed, but remain to be defined.

The cornerstone of current cancer management approaches relies on early detection and on chemotherapeutic and radiologic treatment of diagnosed neoplasms. Although detection methodologies have helped significantly in reducing the lethality associated with cancers such as prostate or breast neoplasms, they have had limited widespread efficacy in many others. Indeed, efforts to diagnose cancers early in their development are still hampered by serious limitations in technologies that cannot detect small tumorigenic growths or disseminated microscopic disease. Similarly, classical anti-neoplastic treatments, which target highly proliferating cancer cells, nondiscriminately target bystander normal cells, such as hair follicle cells or gut-regenerating cells, causing high degree of systemic toxicity. In addition, these systemic therapies, are, to a large extent, inefficient in eradicating disseminated disease, and often result in the emergence of resistance.

The discovery that unchallenged human primary tumors harbor subpopulations of cancer cells that are distinguished from bulk populations by exclusive abilities to self-renew and generate heterogeneous secondary growths refocused attention on understanding the fundamental biology of how these cells emerge, and on identifying means to kill them. Such tumor-initiating cells (TICS), dubbed cancer stem cells (CSCS), which pre-exist already in untreated tumors, were found to be amplified in recurrent disease, and were shown to be highly malignant and with augmented tolerance to existing radio- and chemotherapeutics. ${ }^{3}$ Indeed, it is widely accepted that CSCs represent the root cause for metastatic dissemination and disease relapse in cancer patients. As such, the identification of effective CSC-specific therapeutics has taken center stage in the development of anti-neoplastic therapies aimed at eradicating disease relapse. ${ }^{4}$ 
The molecular underpinnings of the CSC state have been extensively reviewed over the past several years, for example, by Bandhavkar, Kuhlman et al., ${ }^{6}$ and others. ${ }^{7-17}$ The purpose of this article is to briefly summarize and highlight some of the most pertinent concepts surrounding CSC biology, as well as current and emerging therapies targeting CSCs. Bulleted format has been used to provide a more concise presentation of these broad topics to clinicians and researchers interested in an introduction to CSC research.

New anti-neoplastic therapeutic approaches are crucial to improve long-term survival in patients with cancer. Cancer stem cells (CSCS), a subpopulation of tumor cells that self-renew and drive tumorigenesis, are emerging as therapeutic targets that can potentially revolutionize cancer patient management.

\section{Revival of the cancer stem cell hypothesis}

- In the 1860s, Rudolf Virchow observed microscopic similarities between cancer (in this case, teratocarcinoma) and developing embryonic tissues; this led him to postulate that cancers derive from embryonic-like cells. ${ }^{18}$

- The concept that cancers originate from cells with stem cell characteristics was re-formulated by Julius Cohnheim. ${ }^{19,20}$ His theory, termed "embryonal rest hypothesis", stated that cancers initiate from tissue-resident stem cells left over from embryogenesis, which remain dormant in such tissues until reawakened later in life to give rise to cancer.

- Cancer's potential origin from embryonic/germinal-like progenitor cells that are inadvertently stimulated to grow uncontrollably in adult tissues was again entertained by Durante, ${ }^{21}$ Beard, ${ }^{22}$ Rippert, ${ }^{23}$ and Rotter. ${ }^{24}$

- The idea that tumors contain cancer populations with special malignant properties was re-visited by many researchers, such as Hewitt in 1953, who noted that variations in tumor-initiating potential and transplantability exist among varying inocula of sarcoma suspensions, ${ }^{25}$ or by McCulloch et al. in 1971, ${ }^{26}$ who found that tumor colony-forming cells possessed different growth characteristics than their normal counterparts, and that the so-called tumor stem cells represented a very small percentage (0.01-1\%) of the whole tumor population.

- In landmark studies published in 1989, 1994, and 1997,27-29 John Dick's group used a model of acute myeloid leukemia (AML) to definitively show that AML was hierarchical in nature, that cells capable of serially initiating human AML in non-obese diabetic mice with severe combined immunodeficiency disease were rare, and that they possessed selfrenewal, proliferative, and differentiation capacities consistent with "true" leukemia stem cells.

- Chia-Cheng Chang and colleagues isolated two types (type I and II) of antigenically and phenotypically different normal epithelial cells from human breast tissue, and showed that only one type (type I, with luminal characteristics) is prone for transformation by SV40. ${ }^{30}$ Interestingly, type I could be stimulated to generate type II cells (with basal characteristics), prompting the hypothesis that cancers may originate from specialized progenitor-like cells pre-existing in solid tissues.

- Using a model in which human breast cancer cells were grown in immunocompromised mice, Al-Hajj and colleagues demonstrated that not all cancer cells within carcinomas are equally tumorigenic and that only a small subset of cells within such tumors is able to generate secondary tumors when transplanted. ${ }^{31}$ These observations suggested
Table 1: Five-year cancer survival statistics

\begin{tabular}{|l|l|}
\hline Site & 5 -year survival (\%) \\
\hline Bladder & 77 \\
\hline Breast & 89 \\
\hline Colorectal & 65 \\
\hline Kidney & 73 \\
\hline Liver & 17 \\
\hline Lung-non-small cell & 17 \\
\hline Lymphoma-non-Hodgkin & 70 \\
\hline Melanoma & 92 \\
\hline Oral and oropharyngeal cancer & 63 \\
\hline Ovarian, fallopian tube, and peritoneal cancer & 58 \\
\hline Pancreatic & 7 \\
\hline Prostate & 99 \\
\hline Thyroid & 98 \\
\hline Uterine & 82 \\
\hline
\end{tabular}

Data sourced from: www.cancer.net

that solid cancers are, like liquid cancers, ${ }^{28}$ also hierarchical in nature, and harbor a small proportion of so-called tumor-initiating CSCs (also termed TICS).

- Cancer cells from several species were shown to exhibit stark activation patterns in molecular networks that otherwise function as critical regulators of embryonic, adult, and induced pluripotent stem cell homeostasis. ${ }^{32-35}$

- TICS/CSCs have now been identified in multiple malignancies, including multiple leukemias and various solid tumors ${ }^{36}$ such as lung, ${ }^{37}$ colon, ${ }^{38}$ prostate, ${ }^{39}$ ovarian, ${ }^{40}$ brain, ${ }^{41}$ and skin cancers. ${ }^{42}$

- Tumor transplantation studies in histocompatible mice suggested that CSCs can be more abundant than previously estimated, constituting as much as $10 \%$ in leukemias and lymphomas, ${ }^{43}$ and as much as $25 \%$ in melanomas. ${ }^{44}$

- The proportions of CSCs within tumors correlate positively with poor prognosis. ${ }^{45}$

A better understanding of CSC biology will not only lead to conceptual advances in understanding tumour etiology, but will also catalyze the development of important CSC-based anti-neoplastic approaches that have the potential to radically improve cancer management.

\section{Characteristics of cancer stem cells}

- Normal self-renewing adult tissue stem cells give rise to progenitor cells that are often termed transit-amplifying cells which, in turn, divide and proliferate to engender more differentiated cells with restricted proliferating and clonogenic potentials. This hierarchical system calls upon stem cells (which sit at the top of the pyramid) to expand when more differentiated cells (laying at the bottom of the tissue pyramid) are depleted.

- The self-renewing ability of these stem cells ensures their continued presence within tissues and the balance between stem and differentiated cells ascertains tissue homeostasis.

- Normal stem cells are in constant interactions with their microenvironment, or niche, which tightly regulates stem cell state maintenance while controlling the expansion of the stem cell compartment. 
- Tumors are formed of heterogeneous cancer cells that are organized in a hierarchy similar to that of normal tissues, and contain CSCs that share several characteristics with normal stem cells.

- The 2006 American Association for Cancer Research Workshop on Cancer Stem Cells defined a CSC as "a cell within a tumor that possesses the capacity to self-renew and to cause the heterogeneous lineages of cancer cells that comprise the tumor." ${ }^{46}$

- In this model, each tumor contains a sub-population of cells (the CSCs) that are able to divide asymmetrically in order to self-renew and give rise to a phenotypically distinct daughter cell. CSCs are thus considered to be the source of all aggressive plastic cancer cells present in a malignant tumor. ${ }^{2}$

- Even within the CSC compartment, CSCS are heterogeneous, with some possessing short-term repopulating potential while others exhibit longer-term repopulation abilities. ${ }^{47}$

- By virtue of their ability to initiate new tumors, CSCs are thought to represent the cellular seeds responsible for tumor recurrence/relapse and the ones that give rise to distant metastases. ${ }^{2}$

- CSCs shuttle between quiescent and active states, and are characterized by their generally slow proliferating rates. ${ }^{48}$

- CSCS occupy specialized niches or tumor microenvironments (TMES) that maintain stem cell-like properties of such cells via interactions mediated by the extracellular matrix (ECM) and activation of various signal transduction pathways. ${ }^{49,50}$

- CSCs exhibit increased drug resistance activities, attributes that are mediated by multiple mechanisms that include, among others, cell dormancy, hypoxia, enhanced activity of DNA repair enzymes, higher expression of drug efflux transporters (e.g., expression of the ATPbinding cassette $[A B C]$ transporters, such as ABCB1 and ABCG2), ${ }^{51,52}$ and an elevated expression of anti-apoptotic proteins. ${ }^{4}$

- As such, CSCs exhibit increased resistance to standard radio- and chemotherapies. $53-56$

- Multiple stemness pathways are deregulated in CSCs, which include Wnt, tumor growth factor-beta (TGF- $\beta$ ), signal transducer and activator of transcription (STAT), and Hippo-yes associcated protein (YAP)/ transcriptional co-activator with PDZ-binding motif (TAZ) (see Table 2). ${ }^{57}$

- CSCs also evade immune surveillance, which relies on innate and adaptive immune cells recognizing traits of malignant transformation. This occurs via multiple mechanisms that include the following:

- CSCs reduce (and even inhibit) the expression of tumor-associated antigens (TAAS), which limits their recognition and elimination by cytotoxic T cells (CTLS). ${ }^{58}$

- CSCs downregulate the expression of MHC class I molecules.99-61

- CSCs express CD95 and CD95 ligand, which in addition to its autocrine role in promoting CSC state, can kill neighboring CTLS.62,63

- CSCs express "don't eat me" signals, such as CD47, which prevents their phagocytosis by macrophages.64,65

- CSCs may utilize the programmed death-1 (PD-1)/PD ligand-1 (PDL1) system to inhibit the immune system. ${ }^{66,67}$ PD-L1 binds its receptor, PD-1, which is found on multiple immune system cells such as CTLS, natural killer (NK), and dendritic cells. PD-L1/PD-1 signaling is thought to play a major role in inhibiting lymphocyte proliferation, thereby enabling the tumor cells to evade immune surveillance.

- In addition, CSCS secrete immunosuppressive chemokines and cytokines that can inhibit CTL functions (e.g., TGF- $\beta$ and interleukin $10[\mathrm{LL}-10])^{11,68}$
- CSCs may regulate the recruitment of T-reg cells, ${ }^{11}$ which have diverse immune modulatory functions in cancer. ${ }^{69}$

The plasticity of CSCs, their ability to resist standard radiotherapies and chemotherapies, and their capacity to evade immune surveillence position them as key determinants of cancer malignancy.

\section{Identifying cancer stem cells}

- Surface markers can be used to differentiate CSCs from the tumor bulk. Partial phenotypes of CSC markers, organized according to cancer types, are presented in Table $3 .{ }^{36}$

- such antigenic marker profiles have enabled the isolation of human CSCs from heterogeneous tumors using fluorescence-activated cell sorting ${ }^{28}$ or antibodies conjugated to magnetic beads. ${ }^{70}$

- Using these approaches, as well as efflux-based dye labelling (e.g., side population labelling), CSCs have been isolated from multiple solid and liquid tumors, including leukemias, lung, colon, prostate, ovarian, brain, and skin cancers, ${ }^{36-22}$ to name a few. For example:

- Leukemia stem cells (LSC) display a CD34+CD38- phenotype; ${ }^{28}$ the "true" CSCs can also be CD123+ or IL3-alpha+.71

- Certain breast CSCs have a CD44+CD24 phenotype. ${ }^{+}$

- Brain CSCs are also CD133+, similar to brain stem and progenitor cells. $^{72}$

- Ovarian CSCS are CD117+ and CD133+.73

- Three major in vitro and in vivo functional assays have been used to characterize CSCs:

- In vitro colony-forming assay, ${ }^{74}$ which relies on the ability of CSC-like cells to form colonies (or tumorspheres) under serial passages in three-dimensional cultures.

- Limiting dilution analyses (LDA), which test the ability of CSCS to initiate tumors at low cell densities in immunodeficient mice. ${ }^{55}$

- Transplantability assays, which test the abilities of CSC-like cells to regenerate the tumor bulk once transplanted into animals, and the transplantability of these cells from one animal into another. ${ }^{28}$

Surface marker analyses have been instrumental in the identification of cSCs from bulk tumors, but it is important to note that such markers are not universal, even within the same tumor type, and that they result in the underestimation of CSC content in a certain tissue. In addition, the mechanical and/or enzymatic disruption of tumor tissues prior to the antibody-mediated isolation of putative CSCS from such preparations stands to alter the antigenic profiles of CSCs. Similarly, it is also important to note that the estimate of CSC content in tumors using the LDA approach is complicated by the fact that tumor-initiation efficiency in recipient mice depends on the level of immune deficiency present in these recipient animals. ${ }^{27}$

\section{Cancer stem cell genesis}

\section{Cancer stem cell genesis models}

- In the hierarchical model, cancer is thought to initiate from stem/ progenitor cells with intrinsic capacities for self-generation. Accordingly, tumors are viewed as hierarchical pyramids whereby, at the peak, CSCS can self-renew while generating non-CSC differentiated progeny, which form the rest/base of the pyramid, or the tumor bulk. 
Review Cancer Stem Cells

Table 2: Examples of targeted stemness pathways under clinical investigation ${ }^{57}$

\begin{tabular}{|c|c|c|c|}
\hline Tumor type & Agent & Target & Phase \\
\hline Breast & Vantictumaba with SOC chemotherapy & Wnt & I \\
\hline CLL, relapsed/refractory & Duvelisib ${ }^{b}$ & PI3K Delta/PI3K Gamma & III \\
\hline Colorectal & Napabucasinc & STAT & $\|/\| I I$ \\
\hline Gastric & Napabucasinc & STAT & III \\
\hline Gastrointestinal & Napabucasinc & STAT & $\|/\| I I$ \\
\hline Glioblastoma & Napabucasinc & STAT & $\|$ \\
\hline \multirow[t]{2}{*}{ Hematologic malignancies } & Napabucasin ${ }^{c}$ & STAT & 1 \\
\hline & Bronticuzumabe & Notch & la \\
\hline Hepatobilary cancer & Amcasertib $^{d}$ & Broad spectrum, incl. Nanog & $\|$ \\
\hline Hepatocellular carcinoma & Napabucasin ${ }^{c}$ & STAT & I \\
\hline iNHL, refractory & Duvelisibb & PI3K Delta/PI3K Gamma & $\|$ \\
\hline \multirow[t]{3}{*}{ Non-small cell lung cancer } & Defactinibf with pembrolizumab & & \\
\hline & FAK/PYK2 & I/Ib & \\
\hline & Demcizumabs plus SOC chemotherapy & Notch & $\|$ \\
\hline \multirow[t]{2}{*}{ Small cell lung cancer } & Tarextumabi & Notch & ॥ \\
\hline & Napabucasinc & STAT & III \\
\hline \multirow[t]{4}{*}{ Ovarian } & Amcasertib $^{d}$ & Broad spectrum, incl. Nanog & $\|$ \\
\hline & Defactinib $^{f}$ & FAK/PYK2 & I/Ib \\
\hline & Demcizumabs and paclitaxel & Notch & Ib/II \\
\hline & Ipafricept $\mathrm{t}^{\mathrm{h}}$ with carboplatin/paclitaxel & Wnt & Ib \\
\hline \multirow[t]{4}{*}{ Solid tumors/general } & Bronticuzumabe & Notch & la \\
\hline & OMP-305B83 & DLL4/VEGF & la \\
\hline & Napabucasinc & STAT & $\|$ \\
\hline & Amcasertib $^{d}$ & Broad spectrum, incl. Nanog & 1/II \\
\hline Urologic malignancy & Amcasertib $^{d}$ & Broad spectrum, incl. Nanog & $\|$ \\
\hline T cell lymphoma, relapsed/refractory & Duvelisib ${ }^{b}$ & PI3K Delta/PI3K Gamma & $1 / 1 \mathrm{~b}$ \\
\hline
\end{tabular}

$C L L=$ chronic lymphocytic leukemia; $F C R$ = fludarabine, cyclophosphamide, and rituximab; iNHL = indolent non-Hodgkin's lymphoma; PIJK = phosphoinositide-3-kinase;

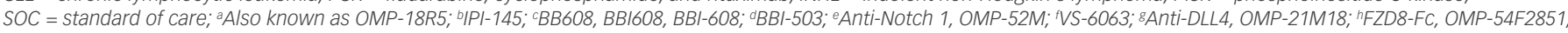
'Anti-Notch 2, OMP-59R5. Data source: Ajani et al. (2015).57 
- Alternatively, the stochastic or clonal evolution model (CE model) posits that a variety of established tumor cells can contribute to generating TICS, in varying degrees, via both intrinsic (e.g., oncogenic lesions) and extrinsic (e.g., microenvironmental) factors such as TGF- $\beta 76$ or hypoxia. ${ }^{77,78}$

- Reconciling these two seemingly opposing theories is the CSC plasticity model, in which the CSC state is a dynamic state that can be gained or lost based on external cues and the innate propensity of the tumor cells to plasticity. Cures according to this model and the stochastic models can only be achieved when treatments result in the death of sufficient numbers of tumor cell populations, hindering possibilities for tumor CSC regeneration and/or expansion (see Figure 1)..$^{79}$

- Of note, Tomasetti and Vogelstein ${ }^{80}$ demonstrated, through statistical analysis, that the lifetime risk of different types of cancer is correlated strongly with the number of divisions of the normal self-renewing cells that maintain the homeostasis of these tissues. Therefore, variation in cancer risk among tissues can be explained by the number of stem cell divisions such tissues undergo, suggesting that tissue-resident stem cells are the origin of tumors or that their high turnover predisposes them to oncogenic mutations.

\section{How cancer stem cells arise}

- There are several proposed hypotheses to explain how CSCs arise, including the following:

- Normal stem cells lose the constraints that limit their self-renewal, and accumulate oncogenic lesions while proliferating. ${ }^{78}$ In this view, normal stem cells themselves give rise to $\operatorname{CSCs} .^{81}$

- More differentiated transit-amplifying cells may acquire oncogenic mutations that cause the aberrant activation of their self-renewal pathways, ${ }^{78}$ leading to their uncontrolled proliferation while inhibiting their terminal differentiation. ${ }^{82}$

- Oncogenic mutations acquired by differentiated cells lead to their dedifferentiation towards more stem-like cells. ${ }^{82-83}$

- Mechanical- and/or chemical-mediated disruption of intercellular communication (e.g., via disruption of gap junctions), postulated a long time ago to be one of the main features of tumor tissues, ${ }^{84}$ can increase the propensity for CSC generation. ${ }^{78}$

- Fusion of normal stem cells and cancer cells, although rare, can also give rise to CSC-like populations within tumors. ${ }^{85}$

- The TME in CSC development:

- The TME contains a variety of cells, including inflammatory and fibroblastic cells, such cancer-associated fibroblasts and mesenchymal stem/stromal cells. These cells affect tumor growth, development and progression in early tumorigenesis and influence the microenvironment to sustain tumor growth as well as secondary tumor formation (metastasis) in other tissues. ${ }^{-94}$

- Co-injection of stromal cells with cancer cells facilitates tumor formation in immune-deficient mice. ${ }^{95-97}$ This suggests that TICS, hence CSC-like cells, are indeed aided by microenvironmental factors produced by surrounding stromal cells.

- The TME may facilitate the plethora of CSC characteristics that allow a tumor cell to accumulate enough epigenetic and genetic changes over time to become highly malignant. ${ }^{98}$ Importantly, CSC-niche cross-talk may occur whereby the niche might not only regulate CSC traits, but may directly provide CSC traits to non-CSCs.9

- CSCs may foster a favorable niche by promoting the formation of a reactive TME. ${ }^{50}$ For example, secretion of TGF- $\beta 2 / T G F-\beta 3$ from
Figure 1: Cancer stem cell models

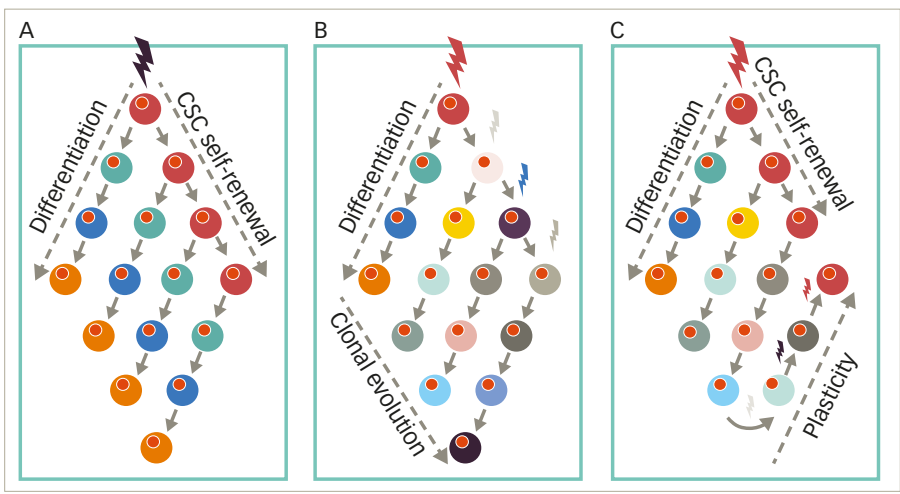

Hierarchical model (A), stochastic (B), and plasticity model (C).

breast cancer cells that disseminated to the lung has been shown to induce stromal fibroblast expression of periostin (POSTN), which is a component of the ECM. In turn, TME-derived POSTN induces recruitment of Wht ligands, which increase Wht signaling in the metastasis-initiating CSCS. ${ }^{100}$

- Hypoxia in CSC development:

- Hypoxia actively induces and maintains CSC phenotype, $98,01,102$ for example, in breast cancer ${ }^{10}$ and glioblastoma. ${ }^{103}$

- The effects of hypoxia on CSCs seem to be primarily mediated by hypoxia inducible factors (HIFs), particularly HIF2 $\alpha .{ }^{101}$

- Hypoxia induces a spectrum of changes that may contribute to malignancy including the selection of apoptosis-resistant clones $^{104}$ and promotion of tumor invasion and metastasis. ${ }^{105}$

- HIF inhibitors can block chemotherapy-induced enrichment of CSCS, suggesting that HIFs play critical functional roles in CSC biology, and that their inhibition may increase survival in patients. ${ }^{10}$

- The epithelial-mesenchymal transition (EMT) in CSC development:

- The EMT is a crucial developmental program often activated during cancer invasion and metastasis. During this process, polarized epithelial cells are converted to mesenchymal cell-like migratory tumor cells. ${ }^{106,107}$

- Transcription factors that regulate migration and EMT in embryonic tissues regulate EMT in cancer cells. ${ }^{108}$

- Several findings have indicated a direct link between the EMT and gain of epithelial stem-cell properties. ${ }^{109,110}$

- Many EMT transcription factors, including zinc finger protein SNAI1 (also referred to as Snail), zinc finger E-box-binding (ZEB) and basic helix-loop-helix transcription factors, ${ }^{108}$ have been shown to regulate CSC phenotype and function in breast, pancreatic, and colorectal tumors. ${ }^{99}$

- EMT transcription factor pathways promote additional malignancy traits ascribed to CSCS, including therapy resistance and anti-apoptosis. ${ }^{111-113}$

- Stiffness/tensegrity in CSC development:

- Growing evidence indicates that physical constraints, such as stiffness and porosity of the ECM, can influence tumor behavior as a whole.

- For example, matrix stiffness increased the proportion of human head and neck squamous cell carcinoma (HNSCC) TICS, concomitant with inducing higher tumorigenicity and metastasis. ${ }^{114}$

- High matrix stiffness promotes proliferation and increased chemotherapeutic resistance in hepatocellular carcinoma cells. ${ }^{115}$ 
- Fusion:

- One other possible but controversial potential mechanism for the generation of CSCs is through fusion between stem cells and differentiated cells. ${ }^{85}$

Evidence indicates that CSCs may be generated and maintained by a plethora of mechanisms that can depend on genetic and epigenetic properties intrinsic to cancer cells, as well as on extrinsic stimuli emanating from the TME or niche. What is clear is that some CSCs are "born" while others are "made" by the tumor milieu. Although these notions can seem contradictory, it is attractive to postulate that both operate in tumors, and that the extent to which one mechanism is empahsized over the other depends on the stage of tumor progression.

\section{Signaling networks in the makeup of the cancer stem cell state}

- The ability of CSCs to retain their properties is determined by an array of signaling networks that are responsive to intrinsic and extrinsic stimuli.

- Pathway elements that play a role in the control of self-renewal and differentiation of CSCs include:

- Phosphatidylinositol-3-kinase (PI3K)/Akt and the mammalian target of rapamycin (mTOR) pathway activation are critical regulators of cell proliferation and survival. Increasing reports have also underscored the importance of PI3K in regulating the CSC state. ${ }^{116,117}$

- The Janus-activated kinase (JAK) signaling pathway has been implicated in tumorigenesis through STAT-3 activation. ${ }^{118}$ Blockade of JAK-STAT has been shown to inhibit tumor initiation and clonogenic recovery of prostate CSCS, substantiating a role for this pathway in tumor initiation. ${ }^{119}$

- Nuclear factor-kappa B (NF-кB) is an inducible transcription factor that affects the expression of several apoptosis-related proteins and cell cycle regulatory components. It has been shown to be upregulated in many cancers, and has been implicated in CSC genesis, as well as promoting invasion and metastasis. ${ }^{120}$

- Mammals express four transmembrane Notch receptors (Notch-1, $-2,-3$, and -4$)^{121}$ and five canonical transmembrane ligands (Delta-like [DLL] 1, DLL3, DLL 4, Jagged-1, and Jagged-2). ${ }^{122-125}$ Notch signaling is an evolutionarily conserved pathway involved in the control of cell fate, with roles in carcinogenesis, tumor angiogenesis, and EMT. ${ }^{26}$ Overexpression of Notch signaling components has been reported to promote self-renewal of CSCs in a variety of malignancies and is involved in the interaction between the tumor and the stroma in both primary and metastatic tumors. ${ }^{127,128}$

- Hedgehog is a key morphogen regulating embryonic development and tissue repair. It has been implicated in the maintenance of the CSC phenotype. ${ }^{129}$ Interestingly, it regulates the expression of the ATPbinding cassette sub-family $\mathrm{G}$ member 2 and multi-drug resistance genes, implying involvement of Hedgehog overexpression in the development of the chemoresistance characteristic of CSCS. ${ }^{130-133}$

- Wingless/integration (Wnt) signal transduction pathways play an important role in cell fate specification, cell proliferation, and cell migration. When aberrantly expressed, Wht contributes to the tumorigenic potential of CSCS. ${ }^{134,135}$

- The YAP and TAZ are the major downstream effectors of the Hippo pathway, which regulates tissue homeostasis, organ size, regeneration, and tumorigenesis. ${ }^{136}$ YAP and TAZ are regulated by soluble extracellular factors, cell-cell adhesion, and mechanotransduction, and such regulation appears to be disrupted in cancer. ${ }^{137-140}$

- Enhanced nuclear accumulation of YAP1, due to upstream inhibition of Hippo signaling, has been shown to increase epidermal squamous cell carcinoma spheroid formation, invasion, and migration. ${ }^{141}$ Hippo pathway inhibition has also been shown to be a requirement for the enhanced migratory and invasiveness properties of breast cancer cells. ${ }^{122}$ In breast CSC, TAZ activity sustains self-renewal and tumor initiation. ${ }^{143}$

- Focal adhesion kinase (FAK) is a non-receptor tyrosine kinase, overexpressed in cancer, with roles in adhesion, survival, motility, metastasis, angiogenesis, and lymphangiogenesis. Involvement of FAK in CSC functions have also been reported. ${ }^{144,145}$

- Homeobox (HOX) genes are an evolutionarily highly conserved family of proteins with demonstrated regulatory roles in cell fate determination. ${ }^{123}$ Members of the HOX gene family have been implicated in tumor development and progression. ${ }^{146}$ Cross talk between HOX and other CSC-regulating mediators, such as sonic hedgehog, Wnt, and Notch signaling pathways ${ }^{147}$ suggest a central role for HOX in CSC homeostasis, and underscore its potential as a credible therapeutic target in the context of CSC-based therapy.

- EMT transcription factors (e.g., SNAIL, TWIST, Zinc finger protein SNAI2/SLUG) are induced during carcinoma progression ${ }^{148}$ and they exert critical determining roles in the promotion/genesis and in the maintenance of CSC traits. ${ }^{199}$

- Bmi-1, a polycomb family proto-oncogene, is required for the selfrenewal of diverse adult stem cells. It promotes stem cell self-renewal partly by repressing the expression of the tumor suppressor genes Ink4a and Arf. ${ }^{150}$ Roles for Bmi in CSC regulation have been described in breast cancer, ${ }^{151}$ leukemias, ${ }^{152}$ prostate cancer, ${ }^{153}$ pancreatic cancer, ${ }^{154}$ and in many other malignancies.

- Various protein kinase $\mathrm{C}$ isoforms have been implicated in the renewal of normal and CSCS. ${ }^{155}$ For example, PKC-iota (PKCi) was shown to promote CSC traits in ovarian carcinoma cells. ${ }^{156}$ Similarly, atypical PKC (aPKC) was shown to promote CSC-like EMT traits in a model of prostate cancer. ${ }^{157,158}$

The CSC state is maintained by the interplay of various signaling pathways. The complexity of these networks ensures redundancy in the maintenance of cancer cell stemness, and stands to frustrate therapeutic efforts aimed at inhibiting single molecular nodes. Renewed CSC-targeted therapies with clinical applicability therefore have to encompass the simultaneous inhibition of several critical targets to achieve clinical efficacy.

\section{Cancer stem cells at the crossroads of metastasis and therapy resistance} Metastasis

- CSCs have been hypothesized to contribute directly to metastasis. Indeed, secondary tumors are initiated by cancer cells with the capacities of making new growths, drawing strong parallels between the CSC state and the metastatic state. ${ }^{159,160}$

- Primary tumors derived from the implantation of CSCs isolated by the putative stem cell markers CD44 ${ }^{+}$and CD24-1/ow generate abundant lung metastases, ${ }^{161}$ suggesting that TICS within primary tumors can generate metastatic CSCS. 
- There are strong functional links between CSC markers and metastatic phenotypes. For example, CSC-associated CD44 is a homing and adhesion marker, and it has demonstrated activities in enhancing metastatic capabilities. ${ }^{31,162}$

- Although CSC preponderance in primary tumors has been correlated with an increased incidence of metastasis, a causal relationship between the primary tumor CSCs and the cells-of-origin of distant metastases has not been proven. ${ }^{163}$

\section{Therapy resistance}

- Drug resistance invariably develops in most cancer patients on therapeutic regimens, limiting outcome and long-term survival. ${ }^{164,165}$

- Better understanding of how drug-resistance develops during initial tumor response and regression will lead to the development of more effective therapeutic modalities.

- For example, therapeutic inhibition of oncogenic drivers in drugsensitive cancer cells has been shown to induce secretome changes that, paradoxically, establish a TME that supports the expansion of drugresistant clones. ${ }^{166}$

- Mounting evidence suggests that therapy-resistant clones share a great deal of similarities with CSCs. ${ }^{167}$

- Indeed, evidence from several cancers indicates that CSCS are highly resistant to ionizing radiation, ${ }^{168-176}$ as well as chemotherapy. ${ }^{171,177}$

- Underlying mechanisms through which CSCs resist therapy include:

- high free radical scavenger status; ${ }^{168,178}$

- cell-type specific fuctuations in proteasome activity; 179,180

- expression of the $A B C B 5$ multi-drug resistance protein; ${ }^{181}$

- enhanced DNA repair capacities and the ability to maintain low ROS content; ${ }^{182}$

- upregulation of oncogenic pathways, ${ }^{183}$

- upregulation of anti-apoptotic nodes, such as survivin; ${ }^{184}$

- upregulation of stem-cell-regulating master genes, such as Oct4. ${ }^{185-188}$

CSCs have been strongly linked to metastatic dissemination and therapeutic resistance. Prevention of tumor relapse therefore depends on eliminating CSCs, derailing their development under classical therapeutic management, or inhibiting the reawakening of disseminated tumor cells from dormancy.

\section{Therapeutic opportunities for cancer stem cell- based therapies}

- Resistance of CSCS to current chemotherapeutics and radiotherapies are major factors contributing to cancer recurrence. ${ }^{4}$

- CSCs have been shown to be essential for tumor pathogenesis and CSC targeting has proven to be effective in suppressing tumor development in a number of pre-clinical proof-of-principle experiments. ${ }^{181,189}$

- CSC-based therapeutics therefore represent an attractive route towards developing cancer cures, and are aimed at interfering with the functions of surface markers, drug efflux channels, stemness pathways, epigenetic regulators, as well as key oncogenic signaling nodes that are essential for CSC homeostasis. Differentiation therapies as well as immunotherapeutics are also being developed with CSCs as their focused targets.

- Complicating these efforts, however, are the facts that not all CSCS express specific and exclusive markers, ${ }^{16}$ and that they may have dynamic phenotypes and genotypes, ${ }^{190}$ raising the difficulty in developing effective CSC-targeted therapies.
Table 3: Markers of cancer stem cells according to tumor tissue origin

\begin{tabular}{|c|c|c|}
\hline Cancer type & Marker & Reference \\
\hline Brain & CD133, CD90 & $\begin{array}{l}\text { Singh et al., } 2003^{220} \\
\text { He et al., 2012 }\end{array}$ \\
\hline Breast & ESA, CD44, CD24, ALDH & $\begin{array}{l}\text { Al-Hajj M et al., } 2003^{31} \\
\text { Ginestier et al., } 2007^{222}\end{array}$ \\
\hline Colorectal & $\begin{array}{l}\text { ESA, CD133, CD166, } \\
\text { CD44, CD24, ALDH }\end{array}$ & $\begin{array}{l}\text { Vaiopoulos et al., } 2012^{223} \\
\text { Cherciu et al., 2014224,225 } \\
\text { Huang et al., 2009226 }\end{array}$ \\
\hline Endometrial & CD133 & Rutella et al., $2009^{227}$ \\
\hline Gastric & CD44 & $\begin{array}{l}\text { Takaishi et al., } 2009^{228} \\
\text { Zhao et al., } 2015^{79}\end{array}$ \\
\hline Head and neck & $\mathrm{CD} 44, \mathrm{CD} 24, \mathrm{ALDH}$ & Han J et al., $2014^{229}$ \\
\hline Hematologic & CD34, CD38 & Lapidot et al., 1994²7 \\
\hline Leukemia & $\begin{array}{l}\text { CD34, CD38, CD47, CCL-1, } \\
\text { CD96, TIM3, CD32, CD25 }\end{array}$ & $\begin{array}{l}\text { Bonnet and Dick, } 1997^{28} \\
\text { Majeti et al., 2009230 } \\
\text { van Rhenen et al., 2007231 } \\
\text { Hosen et al., 2007232 } \\
\text { Jan et al.,2011233 } \\
\text { Saito et al., 2010234 }\end{array}$ \\
\hline Liver & $\begin{array}{l}\text { ESA, CD133, CD90, CD44, } \\
\text { CD24, ALDH }\end{array}$ & $\begin{array}{l}\text { Yamashita and Wang, } 2013^{235} \\
\text { Ma et al., 2008 }\end{array}$ \\
\hline Lung & $\begin{array}{l}\text { CD133, CD44, CD90, } \\
\text { ABCG2 or CXCR4 }\end{array}$ & $\begin{array}{l}\text { Alamgeer et al., 2013237 } \\
\text { Donnenberg et al., 2007238 } \\
\text { Bertolini et al., 2009239 }\end{array}$ \\
\hline Melanoma & ALDH & Boonyaratanakornkit et al., $2010^{240}$ \\
\hline Ovarian & $\mathrm{CD} 44^{+}, \mathrm{C}-\mathrm{Kit}$ & Zhang et al., $2008^{240}$ \\
\hline Pancreatic & $\begin{array}{l}\text { ESA, CD44, CD24, CXCR4, } \\
\text { ALDH }\end{array}$ & $\begin{array}{l}\text { Li et al., 2014242 } \\
\text { Herman et al., 2007162 }\end{array}$ \\
\hline Prostate & integrin $\alpha 2 \beta 1, \mathrm{CD}_{4} 4^{+}$ & Collings et al., $2005^{39}$ \\
\hline
\end{tabular}

$A L D H=$ aldehyde dehydrogenase; $C L L=C$-type lectin-like molecule-1; ESA = epithelial-specific antigen.

- Nevertheless, many novel and innovative approaches are in different stages of drug development and clinical testing, and some targets/ pathways are enumerated here for illustration purposes.

- CD133. Interest has grown in the use of monoclonal antibodies to target CSC surface markers. One example of this is CD133 (prominin-1), a cell surface glycoprotein that is expressed widely in solid tumors (see Table 3), and which has been associated with drugresistant phenotypes and poor prognosis. ${ }^{191}$ CD133-positivity marks CSCs in a variety of tumors, including colon, ${ }^{192}$ brain, $72,193,194$ and lung. ${ }^{195}$ Anti-CD133 cell therapy has been tested and shown to reduce the proliferative capacities of TICS. 196

- PI3K/mTOR. The PI3K/mTOR signaling pathway, a key regulator in cancer progression and CSC survival, is targeted by VS-5584 (Verastem), which is an inhibitor of PI3K, mTORC1, and MTORC2 that preferentially destroys CSCs. Verastem is currently conducting a phase I trial of VS-5584 in patients with advanced cancer (ClinicalTrials.gov identifier NCT01991938). Biomarkers of response to VS-5584 will also be assessed in archival tumor tissue, tumor biopsies (in consenting subjects), and blood samples.

- $A B C$. The ABC-driven efflux transporters are largely responsible for chemoresistance, ${ }^{197}$ and all the mechanisms involved in ATP transporter modulation may be potential therapeutic targets. Numerous members 
of $\mathrm{ABC}$ transporters have been described, although only a few are known to be expressed in human CSCs: multidrug resistance 1 (MDR1) or P-glycoprotein (Pgp)/ABCB1, multidrug resistance protein 1 (MRP1/ $\mathrm{ABCB} 1)$, breast cancer resistance protein (9BCRP), and the melanomaassociated, chemoresistance mediator, ABCB5. Schatton et al. ${ }^{181}$ identified a subpopulation enriched for human malignant melanomainitiating cells (MMICS) that was defined by expression of $A B C B 5$ and showed that specific targeting of this population inhibits tumor growth. Drugs targeting $A B C$ transporters have had limited efficacy in clinical trials so far; however, they may prove more effective if used in combination with other anticancer agents that target CSCS. ${ }^{191}$

- Notch. As one of the most intensely studied potential therapeutic targets, several inhibitors of the Notch pathway are being developed. ${ }^{126}$ These include monoclonal antibodies targeted against Notch receptors or Notch ligands and blocking peptides and inhibitors of the Notch inhibitor $\gamma$-secretase (GSIS). Demcizumab is a humanized immunoglobulin G2 antibody that binds to DeltaLike Ligand 4 (Drosophila, DLL4), and is being studied in an ongoing phase $1 \mathrm{~b}$ dose escalation study in combination with pemetrexed and carboplatin in chemotherapy-naïve stage IIIb/IV non-squamous non-small cell lung cancer. ${ }^{198}$

- Focal adhesion kinase (FAK). FAK inhibitors under study include defactinib (VS-6063) and VS-4718, NVP-TAE-226, pyrrolopyrimidines, and PND-1186. ${ }^{145}$ VS-4718 is currently being investigated in subjects with metastatic non-hematologic malignancies (NCT 01849744) (Table 3).

- Wnt. Several agents have been developed for targeting of this pathway, e.g., OMP-54F28, rofecoxib; PRI-724, CWP232291; and monoclonal antibody against frizzled receptors, vanituctumab. ${ }^{199}$

- Nanog. Amcasertib (BBI503) is an orally administered investigational agent designed to inhibit Nanog and other cancer stem cell pathways by targeting kinases. ${ }^{200} \mathrm{~A}$ dose escalation study $(n=26)$ established the recommended dose of amcasertib at $300 \mathrm{mg} /$ day. Prolonged disease stabilization was reported in several heavily pre-treated patients and phase II trials are ongoing.

- STAT3. STAT3 activity has been shown to regulate self-renewal of CSCS. ${ }^{201,202}$ In phase Ib/II trials, the STAT3 inhibitor, napabucasin (BBI608), has shown promising anticancer activity when used in combination with other agents across advanced, pretreated and untreated metastatic pancreatic cancers, as well as advanced, pretreated colorectal cancer. ${ }^{203-205}$ Napabucasin plus weekly paclitaxel in the treatment of gastric and gastroesophageal junction cancer is being studied in the phase III BRIGHTER trial (NCT02178956). The final data collection date for primary outcome measure for the BRIGHTER Trial is August 2017. Napabucasin is also being studied (phase III) in colorectal cancer (CanStem303C, NCT02753127) and pancreatic cancer (CanStem111P, NCT02993731).

- Hedgehog. There is compelling evidence to suggest that inhibition of Hedgehog signaling in CSCs results in loss of stemness, as supported by a reduction in clonogenicity and pluripotency markers, thereby limiting the characteristics that would otherwise support chemoresistance. Targeting of CSCs and tumor bulk with Hedgehog inhibitors and conventional chemotherapeutics and/or radiation is thus a potential approach to prevent tumor relapse and improve patient outcomes. ${ }^{206}$

- CXCL12. CXCL12, also known as stromal-derived factor-1, is a chemokine that binds its receptor, CXCR4, and is involved in migration, invasion and survival of normal and malignant cells. ${ }^{207}$ Involvement of CXCL12 in regulating several aspects of CSC biology has been documented, ${ }^{208}$ and its inhibitors show promise in experimental models. ${ }^{209}$

- CD47. CD47 represents a "don't eat me signal" in CSCs and plays a significant role in inhibiting their phagocytosis; CD47 inhibition therefore could enhance immune cell (e.g., macrophage) -mediated elimination of $\mathrm{CSCS}^{210-212}$ Leukemia stem cell function in murine xenotransplantation models of AML has been reported to depend on inhibition of macrophages via the immunoglobulin superfamily receptor, SIRP $\alpha .{ }^{213}$ Disrupting SIRP $\alpha$ signaling in macrophages by preventing engagement with its ligand, CD47, eliminated AML stem cells in the xenografts. Also, blocking CD47 signaling has been shown to promote engulfment of pancreatic neuroendocrine tumor cells by macrophages in vitro and inhibited xenograft tumor growth, preventing metastases, and prolonging survival in vivo. ${ }^{214}$

- Interleukin-4 (IL-4). IL-4-mediated drug resistance has been demonstrated in colon $\mathrm{CSCS}_{1}{ }^{215}$ providing the rationale for anti-IL-4 antibody or IL-4 receptor-alpha antagonists as anti-tumor therapies.

- Proteasome. Glioma stem cell (GSCS) have been shown to be 1,000-fold more sensitive to proteasomal inhibition compared with differentiated controls, ${ }^{216}$ which provides a further new potential strategy for targeting stem cells versus bulk cancer cells.

- Tenascin. Emerging evidence on additional mechanisms by which cSCs evade immune surveillance may enable the development of novel therapeutics. For example, cscs derived from either prostate draining lymph nodes (PDLN) or mice harboring oncogene-driven prostate intraepithelial neoplasia (MPIN) use the ECM protein, Tenascin-C, to arrest T-cell activation by interacting with $\alpha 5 \beta 1$ and blocking reorganization of actin-based cytoskeleton. ${ }^{217}$

Translational strategies aimed at targeting CSCs are well underway, with many in advanced pre-clinical stages and others in bona fide clinical trials. Considering that the mulitple and often redundant number of pathways that uphold the CSC state, it is likely that combinatorial use of the aforementioned agents, with or without chemo- or radiotherapies, would prove most advantageous in disease management. It is also hoped that such CSC-directed approaches will reduce the toxicity associated with traditional cancer therapies, promoting longer patient survival, while ensuring appropriate quality of life metrics.

\section{Concluding remarks}

CSCs mediate tumor metastasis and, by their increased resistance to chemotherapy and radiation therapy, contribute to treatment failures and disease relapse. ${ }^{218} \mathrm{CSC}$-targeted therapies therefore have the potential to achieve higher efficacy and remission rates than standard regimens, and stand to revolutionize cancer management.

With this optimistic view comes the inherent plasticity of CSCs, which enables them to transition between CSC and non-CSC states as cells exhibit both functional and phenotypic heterogeneity. ${ }^{219}$ In this scenario, targeting specific CSC populations may ultimately prove futile. Rather, the potential of CSC-directed therapies may be more realized in conjunction with existing chemo- and radiotherapies (or even immunotherapies). Indeed, comprehensive combination strategies have been suggested to improve cancer treatments, which rely on, for example, a ligand targeting CSC, an ABC transporter inhibitor to overcome drug resistance, coupled with an imaging agent to facilitate tumor response diagnosis. ${ }^{36}$ 
Ultimately, therapies that target CSCs are hoped to emerge as critical components of avant-garde effective clinical strategies, particularly in malignancies that continue to exhibit high mortality rates, such as pancreatic, brain, and lung cancers. The field has come a long way, and as translational research into CSC biology is gaining pace, the clinical applications of such advances appear to be increasingly tenable. $\mathrm{u}$
1. Siegel R, Ma J, Zou Z, Jemal A, Cancer statistics, 2014, CA: a Cancer Journal for Clinicians, 2014:64:9-29.

2. Dawood S, Austin L, Cristofanilli M, Cancer stem cells: implications for cancer therapy, Oncology (Williston Park), 2014;28:1101-7, 10.

3. Creighton CJ, Li X, Landis M, et al., Residual breast cancers after conventional therapy display mesenchymal as well as tumor-initiating features, Proc Natl Acad Sci U SA, 2009;106:13820-5

4. Vinogradov $S$, Wei $X$, Cancer stem cells and drug resistance: the potential of nanomedicine, Nanomedicine, 2012;7:597-615.

5. Bandhavkar S, Cancer stem cells: a metastasizing menacel, Cancer Med, 2016:5:649-55.

6. Kuhlmann JD, Hein L, Kurth I, et al., Targeting Cancer Stem Cells: Promises and Challenges, Anticancer Agents Med Chem, 2016;16:38-58.

7. Trosko JE, Review paper: cancer stem cells and cancer nonstem cells: from adult stem cells or from reprogramming of differentiated somatic cells, Vet Pathol, 2009:46:176-93.

8. de Sousa EMF, Vermeulen $L$, Wht Signaling in Cancer Stem Cell. Biology, Cancers (Basel). 2016;8.

9. Zanconato F, Cordenonsi M, Piccolo S, YAP/TAZ at the Roots of Cancer, Cancer Cell, 2016;29:783-803.

10. Semenza GL, Regulation of the breast cancer stem cell phenotype by hypoxia-inducible factors, Clin Sci (Lond), 2015;129:1037-45.

11. Plaks V, Kong N, Werb Z, The cancer stem cell niche: how essential is the niche in regulating stemness of tumor cells?, Cell Stem Cell, 2015:16:225-38.

12. Korkaya $\mathrm{H}$, Wicha MS, Selective targeting of cancer stem cells: a new concept in cancer therapeutics, BioDrugs, 2007:21:299-310 3. Ward RI, Dirks PB, Cancer stem cells: at the headwaters of tumo Ward RJ, Dirks PB, Cancer stem cells: at the head
development, Ann Rev Pathol, 2007:2:175-89.

14. Park CY, Tseng D, Weissman IL, Cancer stem cell-directed therapies: recent data from the laboratory and clinic, Mol Ther 2009:17:219-30

15. Nguyen LV, Vanner R, Dirks $P$, Eaves $C J$, Cancer stem cells: an evolving concept, Nature Reviews Cancer, 2012:12:133-43.

16. Visvader JE, Lindeman GJ, Cancer stem cells: current status and evolving complexities, Cell Stem Cell, 2012;10:717-28.

17. Meacham CE, Morrison SJ, Tumour heterogeneity and cancer cel plasticity, Nature, 2013;501:328-37.

18. Virchow R, Die krankhaften Geschwülste, Berlin, Germany: B.d. 1 Hirschwald 1863

19. Cohnheim J, (1839-1884) experimental pathologist, JAMA 1968;206:1561-2

20. Cohnheim J, Ueber entzundung und eiterung, Path Anat Physiol Klin Med, 1867;40:1-79.

21. Durante $F$, Nesso fisio-pathologico tra la struttura dei nei matern e la genesi di alcuni tumori maligni, Arch Memor Observ Chir Pract, 1874:11:217-26.

22. Beard J, Embryological aspects and etiology of carcinoma, Lancet, 1902:1:1758-61.

23. Rippert $\mathrm{H}$, Geschwulstelehre fur Aerzte und Studierende Bonn, 1904.

24. Rotter H, Histogenese der malignen Geschwülste, J Cancer Res Clin, 1922;18:171-208

25. Hewitt HB, Studies of the quantitative transplantation of mouse sarcoma, Br J Cancer, 1953;7:367-83.

26. Park $\mathrm{CH}$, Bergsagel $\mathrm{DE}$, McCulloch EA, Mouse myeloma tumo stem cells: a primary cell culture assay, J Nat/ Cancer Inst, 1971;46:411-22.

27. Lapidot T, Sirard C, Vormoor J, et al., A cell initiating human acute myeloid leukaemia after transplantation into SCID mice, Nature, 1994;367:645-8

28. Bonnet $\mathrm{D}$, Dick JE, Human acute myeloid leukemia is organized as a hierarchy that originates from a primitive hematopoietic cell, Nat Med, 1997:3:730-7.

29. Kamel-Reid S, Letarte M, Sirard C, et al., A model of human acute Iymphoblastic leukemia in immune-deficient SCID mice, Science (New York, NY), 1989:246:1597-600.

30. Kao $\mathrm{CY}$, Nomata $\mathrm{K}$, Oakley CS, et al., Two types of normal human breast epithelial cells derived from reduction mammoplasty: phenotypic characterization and response to SV40 transfection, Carcinogenesis, 1995;16:531-8.

31. Al-Hajj M, Wicha MS, Benito-Hernandez A, et al., Prospective identification of tumorigenic breast cancer cells, Proc Natl Acad SCi U S A, 2003:100:3983-8.

32. Tai MH, Chang CC, Kiupel $\mathrm{M}$, et al., Oct4 expression in adult human stem cells: evidence in support of the stem cell theory of carcinogenesis, Carcinogenesis, 2005;26:495-502.

33. Webster JD, Yuzbasiyan-Gurkan V, Trosko JE, et al., Expression of the embryonic transcription factor Oct4 in canine neoplasms: a potential marker for stem cell subpopulations in neoplasia, vet Pathol, 2007:44:893-900.

34. Ben-Porath I, Thomson MW, Carey VJ, et al., An embryonic stem cell-like gene expression signature in poorly differentiated agressive human tumors, Nat Genet, 2008:40:499-507.

35. Guo W, Keckesova Z, Donaher JL, et al., Slug and Sox9 cooperatively determine the mammary stem cell state, Cell, 2012;148:1015-28.
36. Chen $\mathrm{K}$, Huang $\mathrm{YH}$, Chen JL, Understanding and targeting cancer stem cells: therapeutic implications and challenges, Acta Pharmacol Sin 2013:34:732-40.

37. Kim CF, Jackson EL, Woolfenden $A E$, et al., Identification of bronchioalveolar stem cells in normal lung and lung cancer, Cell, 2005; $121: 823-35$

38. O'Brien CA, Pollett A, Gallinger S, Dick JE, A human colon cancer cell capable of initiating tumour growth in immunodeficient mice, Nature, 2007:445:106-10

39. Collins AT, Berry PA, Hyde C, et al., Prospective identification of tumorigenic prostate cancer stem cells, Cancer Res, 2005:65:10946-51.

40. Szotek PP, Pieretti-Vanmarcke R, Masiakos PT, et al., Ovarian cancer side population defines cells with stem cell-like characteristics and Mullerian Inhibiting Substance responsiveness, Proc Natl Acad Sci U S A, 2006:103:11154-9.

41. Piccirillo SG, Reynolds BA, Zanetti N, et al., Bone morphogenetic proteins inhibit the tumorigenic potential of human brain tumourinitiating cells, Nature, 2006;444:761-5.

42. Fang D, Nguyen TK, Leishear K, et al., A tumorigenic subpopulation with stem cell properties in melanomas, Cancer Res, 2005;65:9328-37

43. Kelly PN, Dakic A, Adams JM, et al., Tumor growth need not be driven by rare cancer stem cells, Science (New York, NY), 2007:317:337.

44. Quintana E, Shackleton M, Sabel MS, et al., Efficient tumour formation by single human melanoma cells, Nature, 2008:456:593-8.

45. Charafe-Jauffret E, Ginestier C, lovino F, et al., Aldehyde dehydrogenase 1-positive cancer stem cells mediate metastasis and poor clinical outcome in inflammatory breast cancer, Clin Cancer Res, 2010;16:45-55.

46. Clarke MF, Dick JE, Dirks PB, et al., Cancer stem cells-perspectives on current status and future directions: $A A C R$ Workshop on cancer stem cells, Cancer Res, 2006;66:9339-44.

47. Hope KJ, Jin L, Dick JE, Acute myeloid leukemia originates from a hierarchy of leukemic stem cell classes that differ in self-renewal capacity, Nat Immunol, 2004;5:738-43.

48. Moore N, Lyle S, Quiescent, slow-cycling stem cell populations in cancer: a review of the evidence and discussion of significance, Journal of Oncology, 2011:2011.

49. Pajonk $F$, Vlashi $E$, Characterization of the stem cell niche and its importance in radiobiological response, Semin Radiat Oncol 2013:23:237-41

50. Castano Z, Fillmore CM, Kim CF, MCAllister SS, The bed and the bugs: interactions between the tumor microenvironment and cancer stem cells, Semin Cancer Biol, 2012;22:462-70.

51. Jiang Y, He Y, Li H, et al., Expressions of putative cancer stem cell markers ABCB1, ABCG2, and CD133 are correlated with the degree of differentiation of gastric cancer, Gastric Cancer, 2012:15:440-50

52. Xie ZY, LV K, Xiong Y, Guo WH, ABCG2-meditated multidrug resistance and tumor-initiating capacity of side population cells from colon cancer, Oncology Research and Treatment, 2014;37:666-8, 70-2

53. Fuchs E, Nowak JA, Building epithelial tissues from skin stem cells, Cold Spring Harb Symp Quant Biol, 2008;73:333-50.

54. Wilson A, Laurenti $\mathrm{E}$ O Oser $\mathrm{G}$, et al., Hematopoietic stem cells reversibly switch from dormancy to self-renewal during homeostasis and repair. Cell, 2008:135:1118-29.

55. van der Flier LG, Clevers $H$, Stem cells, self-renewal, and differentiation in the intestinal epithelium, Annu Rev Physiol 2009;71:241-60

56. Seita J, Weissman IL, Hematopoietic stem cell: self-renewal versus differentiation, Wiley Interdiscip Rev Syst Biol Med, 2010;2:640-53.

57. Ajani JA, Song S, Hochster HS, Steinberg IB, Cancer stem cells: the promise and the potential, Semin Oncol, 2015:42(Suppl 1):S3-17.

58. Khong HT, Wang QJ, Rosenberg SA, Identification of multiple antigens recognized by tumor-infiltrating lymphocytes from a single patient: tumor escape by antigen loss and loss of MHC expression, J Immunother, 2004;27:184-90.

59. Tallerico R, Todaro M, Di Franco S, et al., Human NK cells selective targeting of colon cancer-initiating cells: a role for natural cytotoxicity receptors and $\mathrm{MHC}$ class I molecules, J Immunol, 2013:190:2381-90

60. Di Tomaso T, Mazzoleni S, Wang E, et al., Immunobiological characterization of cancer stem cells isolated from glioblastoma patients, Clin Cancer Res, 2010;16:800-13.

61. Wu A, Wiesner S, Xiao J, et al., Expression of MHC I and NK ligands on human $\mathrm{CD} 133+$ glioma cells: possible targets of immunotherapy, J Neurooncol, 2007;83:121-31.

62. Strand $\mathrm{S}$, Hofmann WJ, Hug H, et al., Lymphocyte apoptosis induced by CD95 (APO-1/Fas) ligand-expressing tumor cells--a mechanism of immune evasion? Nat Med, 1996:2:1361-6.

63. Peter ME, Hadji A, Murmann AE, et al., The role of CD95 and CD95 ligand in cancer, Cell Death Differ, 2015:22:549-59.

64. Zhang H, Lu H, Xiang L, et al., HIF-1 regulates CD47 expression in breast cancer cells to promote evasion of phagocytosis an maintenance of cancer stem cells, Proc Natl Acad Sci U S A

\section{5;112:E6215-23}

65. McCracken MN, Cha AC, Weissman IL, Molecular Pathways: Activating T Cells after Cancer Cell Phagocytosis from Blockade of CD47 "Don't Eat Me" Signals, Clin Cancer Res, 2015;21:3597-601

6. Yan Z, Zhuansun Y, Liu G, et al., Mesenchymal stem cells suppress $T$ cells by inducing apoptosis and through PD-1/B7-H1 interactions, Immunol Lett, 2014;162(1 Pt A):248-55.

67. Luz-Crawford P, Noel D, Fernandez X, et al., Mesenchymal stem cells repress Th17 molecular program through the PD-1 pathway, Plos One, 2012;7:e45272.

68. Xu L, Wang X, Wang J, et al., Hypoxia-induced secretion of IL-10 from adipose-derived mesenchymal stem cell promotes growth and cancer stem cell properties of Burkitt lymphoma, Tumour Biol, 2016;37:7835-42.

69. Whiteside TL, Schuler P, Schilling B, Induced and natural regulatory T cells in human cancer, Expert Opin Biol Ther, 2012:12:1383-97.

70. Gilbert CA, Ross AH, Cancer stem cells: cell culture, markers, and targets for new therapies, J Cell Biochem, 2009;108:1031-8.

71. Jordan CT, Upchurch D, Szilvassy SJ, et al. , The interleukin-3 receptor alpha chain is a unique marker for human acute myelogenous leukemia stem cells, Leukemia, 2000;14:1777-84.

72. Singh SK, Hawkins C, Clarke ID, et al., Identification of human brain tumour initiating cells, Nature, 2004;432:396-401.

73. Stemberger-Papic S, Vrdoljak-Mozetic D, Ostojic DV, et al., Expression of CD133 and CD117 in 64 Serous Ovarian Cancer Cases, Coll Antropol, 2015:39:745-53.

74. Williams SA, Anderson WC, Santaguida MT, Dylla SJ, Patientderived xenografts, the cancer stem cell paradigm, and cancer pathobiology in the 21st century, Lab Invest, 2013;93:970-82.

75. Eirew P, Stingl J, Raouf A, et al., A method for quantifying norma human mammary epithelial stem cells with in vivo regenerative ability, Nat Med, 2008;14:1384-9.

76. Junk DJ, Cipriano R, Bryson BL, et al., Tumor microenvironmental signaling elicits epithelial-mesenchymal plasticity throug cooperation with transforming genetic events, Neoplasia, 2013:15:1100-9.

77. Conley SJ, Gheordunescu E, Kakarala P, et al., Antiangiogenic agents increase breast cancer stem cells via the generation of tumor hypoxia, Proc Natl Acad Sci U S A, 2012;109:2784-9.

78. Trosko JE, Gap junctional intercellular communication as a biological "Rosetta stone" in understanding, in a systems biological manner, stem cell behavior, mechanisms of epigenetic toxicology, chemoprevention and chemotherapy, J Membr Biol, 2007:218:93-100.

79. Zhao Y, Feng F, Zhou YN, Stem cells in gastric cancer, World J Gastroenterol, 2015;21:112-23.

80. Tomasetti C, Vogelstein B, Cancer etiology. Variation in cance risk among tissues can be explained by the number of stem cell divisions. Science, 2015;347:78-81.

81. Schepers AG, Snippert HJ, Stange DE, et al., Lineage tracing reveals Lgr5+ stem cell activity in mouse intestinal adenomas, science, 2012:337:730-5.

82. Helczynska K, Kronblad A, Jogi A, et al., Hypoxia promotes a dedifferentiated phenotype in ductal breast carcinoma in situ, Cancer Res, 2003;63:1441-4

83. Soltysova A, Altanerova V, Altaner C, Cancer stem cells, Neoplasma, 2005;52:435-40.

84. Loewenstein WR, Kanno Y, Intercellular communication and the control of tissue growth: lack of communication between cancer cells, Nature, 1966:209:1248-9.

85. Lu X, Kang Y, Cell fusion hypothesis of the cancer stem cell, Adv Exp Med Biol, 2011;714:129-40.

86. Li F, Tiede B, Massague J, Kang Y, Beyond tumorigenesis: cancer stem cells in metastasis, Cell Res, 2007;17:3-14

87. Cammarota F, Laukkanen MO, Mesenchymal Stem/Stromal Cells in Stromal Evolution and Cancer Progression, Stem Cells Int 2016;2016:4824573.

88. Santamaria-Martinez A, Barquinero I, Barbosa-Desongles A, et al., Identification of multipotent mesenchymal stromal cells in the reactive stroma of a prostate cancer xenograft by side population analysis, Exp Cell Res, 2009;315:3004-13.

89. Tamimi SO, Ahmed A, Stromal changes in invasive breast carcinoma: an ultrastructural study, J Pathol, 1987;153:163-70.

90. van der Horst G, Bos L, van der Pluijm G, Epithelial plasticity, cancer stem cells, and the tumor-supportive stroma in bladder carcinoma, Mol Cancer Res, 2012:10:995-1009.

91. Liu R, Wei S, Chen J, Xu S, Mesenchymal stem cells in lung cancer tumor microenvironment: their biological properties, influence on tumor growth and therapeutic implications, Cancer Lett, 2014;353:145-52.

92. Calon A, Lonardo E, Berenguer-Llergo A, et al., Stromal gene expression defines poor-prognosis subtypes in colorectal cancer, Nat Genet, 2015;47:320-9.

93. Isella C, Terrasi A, Bellomo SE, et al.. Stromal contribution to the colorectal cancer transcriptome, Nat Genet, 2015:47:312-9.

94. Choi H, Sheng J, Gao D, et al., Transcriptome analysis of individual stromal cell populations identifies stroma-tumor crosstalk in mouse lung cancer model, Cell Reports, 2015;10:1187-201. 
95. Margolin DA, Silinsky J, Grimes C, et al., Lymph node stromal cells enhance drug-resistant colon cancer cell tumor formation through SDF-1alpha/CXCR4 paracrine signaling, Neoplasia, 2011;13:874-86.

96. Li L, Yoon SO, Fu DD, et al., Novel follicular dendritic cell molecule, $8 D 6$, collaborates with CD44 in supporting lymphomagenesis by a Burkitt lymphoma cell line, L3055, Blood, 2004;104:815-21.

97. Karnoub AE, Dash AB, Vo AP, et al., Mesenchymal stem cells within tumour stroma promote breast cancer metastasis, Nature, 2007:449:557-63.

98. Lin $\mathrm{Q}$, Yun Z, Impact of the hypoxic tumor microenvironment on the regulation of cancer stem cell characteristics, Cancer Bio Ther, 2010:9:949-56

99. Baccelli I, Trumpp A, The evolving concept of cancer and metastasis stem cells, I Cell Biol, 2012;198:281-93.

100. Malanchi I, Santamaria-Martinez A, Susanto E, et al., Interactions between cancer stem cells and their niche govern metastatic colonization, Nature, 2011;481:85-9.

101. Li Z, Rich JN, Hypoxia and hypoxia inducible factors in cancer stem cell maintenance, Curr Top Microbiol Immunol, 2010:345:21-30.

102. Trosko JE, Kang KS, Evolution of energy metabolism, stem cells and cancer stem cells: how the warburg and barker hypotheses might be linked, J Stem Cells, 2012;5:39-56.

103. Heddleston JM, Li Z, McLendon RE, et al., The hypoxic microenvironment maintains glioblastoma stem cells and promotes reprogramming towards a cancer stem cell phenotype, Cell Cycle, 2009;8:3274-84.

104. Graeber TG, Osmanian C, Jacks T, et al., Hypoxia-mediated selection of cells with diminished apoptotic potential in solid tumours, Nature, 1996:379:88-91.

105. Subarsky P, Hill RP, The hypoxic tumour microenvironment and metastatic progression, Clin Exp Metastasis, 2003;20:237-50

106. Wang KH, Kao AP, Lin TC, et al., Promotion of epithelia mesenchymal transition and tumor growth by 17 beta-estradiol in an ER(+)/HER2(+) cell line derived from human breast epithelial stem cells, Biotechnol Appl Biochem, 2012;59:262-7.

107. Lim J, Thiery JP, Epithelial-mesenchymal transitions: insights from development, Development, 2012:139:3471-86.

108. Lamouille S, Xu J, Derynck R, Molecular mechanisms of epitheliamesenchymal transition, Nat Rev Mol Cell Biol, 2014;15:178-96.

109. Mani SA, Guo W, Liao MJ, et al., The epithelial-mesenchymal transition generates cells with properties of stem cells, Cell 2008;133:704-15.

110. Puisieux A, Brabletz T, Caramel J, Oncogenic roles of EMT-inducing transcription factors, Nat Cell Biol, 2014:16:488-94.

111. Rofstad EK, Microenvironment-induced cancer metastasis, Int J Rad BiOl, 2000:76:589-605.

112. Kong D, Li Y, Wang Z, Sarkar FH, Cancer Stem Cells and Epithelialto-Mesenchymal Transition (EMT)-Phenotypic Cells: Are They Cousins or Twins?, Cancers, 2011;3:716-29.

113. Wu K, Bonavida B, The activated NF-kappaB-Snail-RKIP circuitry in cancer regulates both the metastatic cascade and resistance to apoptosis by cytotoxic drugs, Crit Rev Immunol, 2009:29:241-54.

114. Liu C, Liu Y, XU XX, et al., Potential effect of matrix stiffness on the enrichment of tumor initiating cells under three-dimensional culture conditions, Exp Cell Res, 2015;330:123-34.

115. Schrader J, Gordon-Walker TT, Aucott RL, et al., Matrix stiffness modulates proliferation, chemotherapeutic response, and dormancy in hepatocellular carcinoma cells, Hepatology, 2011;53:1192-205.

116. Porta C, Paglino C, Mosca A, Targeting PI3K/Akt/mTOR Signaling in Cancer, Front Oncol, 2014:4:64.

117. Xia $\mathrm{P}, \mathrm{XU} X \mathrm{XY}, \mathrm{PI} 3 \mathrm{~K} / \mathrm{Akt} / \mathrm{mTOR}$ signaling pathway in cancer stem cells: from basic research to clinical application, Am I Cancer Res, 2015:5:1602-9.

118. Bromberg JF, Wrzeszczynska MH, Devgan G, et al., Stat3 as an oncogene, Cell, 1999;98:295-303

119. Kroon P, Berry PA, Stower MJ, et al., JAK-STAT blockade inhibits tumor initiation and clonogenic recovery of prostate cancer stemlike cells, Cancer Res, 2013;73:5288-98.

120. Amiri KI, Richmond A, Role of nuclear factor-kappa B in melanoma, Cancer Metastasis Rev, 2005:24:301-13.

121. Blaumueller CM, Qi H, Zagouras $\mathrm{P}$, Artavanis-Tsakonas $\mathrm{S}$ Intracellular cleavage of Notch leads to a heterodimeric recepto on the plasma membrane, Cell, 1997;90:281-91.

122. Dunwoodie SL, Henrique D, Harrison SM, Beddington RS, Mouse DII3: a novel divergent Delta gene which may complement the function of other Delta homologues during early pattern formation in the mouse embryo, Development, 1997;124:3065-76.

123. Lindsell CE, Shawber CJ, Boulter J, Weinmaster G, Jagged: a mammalian ligand that activates Notch1, Cell, 1995;80:909-17.

124. Shawber C, Boulter J, Lindsell CE, Weinmaster G, Jagged2: a serrate-like gene expressed during rat embryogenesis, Dev Biol, 1996;180:370-6

125. Callahan $R$, Raafat $A$, Notch signaling in mammary gland tumorigenesis, I Mammary Gland Biol, 2001:6:23-36.

126. Espinoza I, Pochampally R, Xing F, et al., Notch signaling: targeting cancer stem cells and epithelial-to-mesenchymal transition, Onco Targets Ther, 2013:6:1249-59.

127. Gu JW, Rizzo P, Pannuti A, et al., Notch signals in the endothelium and cancer "stem-like" cells: opportunities for cancer therapy, vascular Cell, 2012;4:7

128. Pannuti A, Foreman K, Rizzo P, et al., Targeting Notch to target cancer stem cells, Clin Cancer Res, 2010;16:3141-52.

129. Justilien V, Fields AP, Molecular pathways: novel approaches for improved therapeutic targeting of Hedgehog signaling in cancer stem cells, Clin Cancer Res, 2015;21:505-13

130. Huang FT, Zhuan-Sun YX, Zhuang YY, et al., Inhibition of hedgehog signaling depresses self-renewal of pancreatic cancer stem cells and reverses chemoresistance, Int I Oncol, 2012:41:1707-14.

131. Olive KP, Jacobetz MA, Davidson CJ, et al., Inhibition of Hedgehos signaling enhances delivery of chemotherapy in a mouse model of pancreatic cancer, Science, 2009:324:1457-61.

132. Sims-Mourtada J, Izzo JG, Ajani J, Chao KS, Sonic Hedgehog promotes multiple drug resistance by regulation of drug transport, Oncogene, 2007;26:5674-9.

133. Singh S, Chitkara D, Mehrazin R, et al., Chemoresistance in prostate cancer cells is regulated by miRNAs and Hedgehog pathway, Plos One, 2012:7:e40021.

134. Le PN, MCDermott JD, Jimeno A, Targeting the Wnt pathway in human cancers: therapeutic targeting with a focus on OMP54F28, Pharmacol Ther, 2015;146:1-11.

135. Clevers H, Loh KM, Nusse R, Stem cell signaling. An integral program for tissue renewal and regeneration: Wht signaling and stem cell control, Science, 2014;346:1248012.

136. Moroishi T, Hansen CG, Guan KL, The emerging roles of YAP and TAZ in cancer, Nat Rev Cancer, 2015;15:73-9.

137. Mo JS, Park HW, Guan KL, The Hippo signaling pathway in stem cell biology and cancer, EMBO Reports, 2014;15:642-56.

138. Hayashi H, Higashi T, Yokoyama N, et al., An Imbalance in TAZ and YAP Expression in Hepatocellular Carcinoma Confers Cancer Stem Cell-like Behaviors Contributing to Disease Progression, Cancer Res, 2015;75:4985-97.

139. Chang C, Goel HL, Gao H, et al., A laminin 511 matrix is regulated by TAZ and functions as the ligand for the alpha6Bbeta1 integrin to sustain breast cancer stem cells, Genes Dev, 2015:29:1-6.

140. Song S, Aiani JA, Honjo S, et al., Hippo coactivator YAP1 upregulates SOX9 and endows esophageal cancer cells with stem-like properties, Cancer Res, 2014;74:4170-82.

141. Fisher ML, Kerr C, Adhikary G, et al., Transglutaminase Interaction with alpha6/beta4-Integrin Stimulates YAP1Dependent DeltaNp63alpha Stabilization and Leads to Enhanced Cancer Stem Cell Survival and Tumor Formation, Cancer Res, 2016;76:7265-76.

142. Wang $Y$ Liu t Ying $X$ et al. Twist-mediated Epithelialmesenchymal Transition Promotes Breast Tumor Cell Invasion via Inhibition of Hippo Pathway, Sci Rep, 2016;6:24606.

143. Cordenonsi M, Zanconato F, Azzolin L, et al., The Hippo transduce TAZ confers cancer stem cell-related traits on breast cancer cells, Cell, 2011;147:759-72.

144. Peng X, Ueda H, Zhou H, Stokol T, Shen TL, Alcaraz A, et al., Overexpression of focal adhesion kinase in vascular endothelial cells promotes angiogenesis in transgenic mice, Cardiovasc Res, 2004:64:421-30.

145. Golubovskaya VM, Targeting FAK in human cancer: from finding to first clinical trials, Front Biosci, 2014;19:687-706.

146. Tabuse M, Ohta S, Ohashi Y, et al., Functional analysis of HOXD9 in human gliomas and glioma cancer stem cells, Mol Cancer, 2011;10:60.

147. Sengupta A, Banerjee D, Chandra S, et al., Deregulation and cross talk among Sonic hedgehog, Wnt, Hox and Notch signaling in chronic myeloid leukemia progression, Leukemia, 2007:21:949-55.

148. Hugo H, Ackland ML, Blick T, et al., Epithelial--mesenchymal and mesenchymal-epithelial transitions in carcinoma progression, $J$ Cell Physio, 2007;213:374-83.

149. Fazilaty H, Gardaneh M, Akbari P, et al., SLUG and SOX9 Cooperatively Regulate Tumor Initiating Niche Factors in Breast Cancer, Cancer Microenviron, 2016:9:71-4.

150. Pardal R, Molofsky AV, He S, Morrison SJ, Stem cell self-renewal and cancer cell proliferation are regulated by common networks that balance the activation of proto-oncogenes and tumor suppressors, Cold Spring Harb Symp Quant Biol, 2005;70:177-85.

151. Liu S, Dontu G, Mantle ID, et al., Hedgehog signaling and Bmi-1 regulate self-renewal of normal and malignant human mammary stem cells, Cancer Res, 2006;66:6063-71.

152. Hosen N, Yamane T, Muijtjens M, et al., Bmi-1-green fluorescent protein-knock-in mice reveal the dynamic regulation of bmi-1 expression in normal and leukemic hematopoietic cells, Stem Cells, 2007:25:1635-44.

153. Hurt EM, Kawasaki BT, Klarmann GJ, et al., CD44+ CD24(-) prostate cells are early cancer progenitor/stem cells that provide a model for patients with poor prognosis, $\mathrm{Br} J$ Cancer, 2008;98:756-65.

154. Lee CJ, Dosch J, Simeone DM, Pancreatic cancer stem cells, J Clin Oncol, 2008:26:2806-12.

155. Lee $\mathrm{CY}$, Robinson KJ, Doe CQ, Lgl, Pins and APKC regulate neuroblast self-renewal versus differentiation, Nature, 2006:439:594-8.

156. Wang Y, Hill KS, Fields AP, PKCiota maintains a tumor-initiating cell phenotype that is required for ovarian tumorigenesis, Mol Cancer Res, 2013;11:1624-35.

157. Zhang K, Zhao H, Ji Z, et al., Shp2 promotes metastasis of prostate cancer by attenuating the PAR3/PAR6/aPKC polarity protein complex and enhancing epithelial-to-mesenchymal transition, Oncogene, 2016:35:1271-82.

158. Newton AC, Protein kinase C: structure, function, and regulation, J Biol Chem, 1995;270:28495-8.

159. Shiozawa Y, Nie B, Pienta KJ, et al., Cancer stem cells and their role in metastasis, Pharmacol Ther, 2013;138:285-93.

160. Oskarsson T, Batlle E, Massague J, Metastatic stem cells: sources, niches, and vital pathways, Cell Stem Cell, 2014;14:306-21.

161. Liu H, Patel MR, Prescher JA, et al., Cancer stem cells from human breast tumors are involved in spontaneous metastases in orthotopic mouse models, Proc Natl Acad Sci U S A, 2010;107:18115-20.

162. Hermann PC, Huber SL, Herrler T, et al., Distinct populations of cancer stem cells determine tumor growth and metastatic activity in human pancreatic cancer, Cell Stem Cell, 2007:1:313-23.

163. Phay JE, Ringel MD, Metastatic mechanisms in follicular cellderived thyroid cancer, Endocr Relat Cancer, 2013:20:R307-19.

164. Holohan C, Van Schaeybroeck S, Longley DB, Johnston PG, Cancer drug resistance: an evolving paradigm, Nat Rev Cancer, 2013;13:714-26.

165. Engelman JA, Settleman J, Acquired resistance to tyrosine kinase inhibitors during cancer therapy, Curr Opin Genetics Dev, 2008:18:73-9.

166. Obenauf AC, Zou Y, Ji AL, et al., Therapy-induced tumour secretomes promote resistance and tumour progression, Nature. 2015;520:368-72.

167. Doherty MR, Smigiel JM, Junk DJ, Jackson MW, Cancer Stem Cell Plasticity Drives Therapeutic Resistance, Cancers, 2016;8.

168. Phillips TM, McBride WH, Pajonk F, The response of CD24(-/low)/ CD44+ breast cancer-initiating cells to radiation, J Natl Cancer Inst, 2006;98:1777-85.

169. Woodward WA, Chen MS, Behbod F, et al., WNT/beta-catenin mediates radiation resistance of mouse mammary progenitor cells, Proc Natl Acad Sci U S A, 2007;104:618-23.

170. Bao S, Wu Q, McLendon RE, et al., Glioma stem cells promote radioresistance by preferential activation of the DNA damage response, Nature, 2006;444:756-60.

171. Eramo A, Ricci-Vitiani L, Zeuner A, et al., Chemotherapy resistance of glioblastoma stem cells, Cell Death Differ, 2006;13:1238-41.

172. Chiou SH, Kao CL, Chen YW, et al, Identification of CD133-positive radioresistant cells in atypical teratoid/rhabdoid tumor, Plos One, 2008:3:e2090

173. Blazek ER, Foutch JL, Maki G, Daoy medulloblastoma cells that express CD133 are radioresistant relative to CD133- cells, and the CD133+ sector is enlarged by hypoxia, Int J Radiat Oncol Biol Phys, 2007;67:1-5.

174. Chang CJ, Hsu CC, Yung MC, et al., Enhanced radiosensitivity and radiation-induced apoptosis in glioma CD133-positive cells by knockdown of SirT1 expression, Biochem Biophys Res Commun, 2009;380:236-42.

175. Holtz MS, Forman SJ, Bhatia R, Nonproliferating CML CD34 progenitors are resistant to apoptosis induced by a wide range of proapoptotic stimuli, Leukemia, 2005;19:1034-41

176. Lomonaco SL, Finniss S, Xiang C, et al., The induction of autophagy by gamma-radiation contributes to the radioresistance of glioma stem cells, Int J Cancer, 2009:125:717-22.

177. Fillmore $\mathrm{CM}$, Kuperwasser $\mathrm{C}$, Human breast cancer cell lines contain stem-like cells that self-renew, give rise to phenotypically diverse progeny and survive chemotherapy, Breast Cancer Res, 2008; 10:R25

178. Diehn M, Cho RW, Lobo NA, et al., Association of reactive oxygen species levels and radioresistance in cancer stem cells, Nature, 2009:458:780-3.

179. Vlashi E, Kim K, Lagadec C, et al., In vivo imaging, tracking, and targeting of cancer stem cells, J Natl Cancer Inst, 2009:101:350-9.

180. Gong X, Schwartz PH, Linskey ME, Bota DA, Neural stem/ progenitors and glioma stem-like cells have differential sensitivity to chemotherapy, Neurology, 2011;76:1126-34.

181. Schatton T, Murphy GF, Frank NY, et al., Identification of cells initiating human melanomas, Nature, 2008;451:345-9.

182. Skvortsova I, Debbage P, Kumar V, Skvortsov S, Radiation resistance: Cancer stem cells (CSCS) and their enigmatic prosurvival signaling, Semin Cancer Biol, 2015:35:39-44.

183. Chang L, Graham PH, Hao J, et al., Acquisition of epithelialmesenchymal transition and cancer stem cell phenotypes is associated with activation of the PI3K/Akt/mTOR pathway in prostate cancer radioresistance, Cell Death Dis, 2013;4:e875.

184. Dahan P, Martinez Gala J, Delmas C, et al., Ionizing radiations sustain glioblastoma cell dedifferentiation to a stem-like phenotype through survivin: possible involvement in radioresistance, Cell Death Dis, 2014:5:01543.

185. Ventela S, Sittig E, Mannermaa L, et al., CIP2A is an Oct4 target gene involved in head and neck squamous cell cancer oncogenicity and radioresistance, Oncotarget, 2015:6:144-58.

186. Trosko JE, Human adult stem cells as the target cells for the initiation of carcinogenesis and for the generation of "cancer stem cells", Int J Stem Cells, 2008;1:8-26.

187. Kang KS, Trosko JE, Stem cells in toxicology: fundamental biology and practical considerations, Toxicol Sci, 2011;120(Supp 1):S269-89.

188. Trosko JE, Induction of iPS cells and of cancer stem cells: the stem cell or reprogramming hypothesis of cancer?, Anat Rec, 2014;297:161-73.

189. Bao S, Wu Q, Li Z, et al., Targeting cancer stem cells through L1CAM suppresses glioma growth, Cancer Res, 2008;68:6043-8.

190. Sole RV, Rodriguez-Caso C, Deisboeck TS, Saldana J, Cancer stem cells as the engine of unstable tumor progression, J Theor Biol, 2008:253:629-37.

191. Dragu DL, Necula LG, Bleotu C, et al., Therapies targeting cancer stem cells: Current trends and future challenges, World I Stem Cells, 2015;7:1185-201

192. Vermeulen L, Todaro M, de Sousa Mello F, et al., Single-cell cloning of colon cancer stem cells reveals a multi-lineage differentiation capacity, Proc Natl Acad Sci U S A, 2008;105:13427-32.

193. Beier D, Wischhusen J, Dietmaier W, et al., CD133 expression and cancer stem cells predict prognosis in high-grade oligodendroglial tumors, Brain Pathol, 2008;18:370-7. 
194. Beier D, Rohrl S, Pillai DR, et al., Temozolomide preferentially depletes cancer stem cells in glioblastoma, Cancer Res, 2008;68:5706-15

195. Sarvi S, Mackinnon AC, Avlonitis N, et al., CD133+ cancer stemlike cells in small cell lung cancer are highly tumorigenic and chemoresistant but sensitive to a novel neuropeptide antagonist, Cancer Res, 2014;74:1554-65.

196. Stratford EW, Bostad M, Castro R, et al., Photochemical internalization of CD133-targeting immunotoxins efficiently depletes sarcoma cells with stem-like properties and reduces tumorigenicity, Biochim Biophys Acta, 2013;1830:4235-43.

197. Haraguchi $\mathrm{N}$, Utsunomiya T, Inoue $\mathrm{H}$, et al., Characterization of a side population of cancer cells from human gastrointestinal system, Stem Cells, 2006;24:506-13

198. Kotasek D, Hughes B, Markman B, et al., A Phase 1b Study of the Anti-Cancer Stem Cell Agent Demcizumab, Pemetrexed and Carboplatin in Patients with 1st line Non-Squamous Non-Small Cell Lung Cancer (NSCLC), J Clin Oncol, 2015;33(suppl; abstract 8045).

199. Jimeno A, Gordon MS, Chugh R, et al., A first-in-human phase 1 study of anticancer stem cell agent OMP-54F28 (FZD8-FC), decoy receptor for WNT ligands, in patients with advanced solid tumors, J Clin Oncol, 2014:32(5s): (suppl; abstract 2505).

200. Laurie SA, Jonker DJ, Edenfield WJ, et al., A phase 1 doseescalation study of BBI503, a first-in-class cancer stemness kinase inhibitor in adult patients with advanced solid tumors. Presented at 2014 American Society of Clinical Oncology (ASCO) Annual Meeting; Chicago, IL, USA, 2014.

201. Li Y, Rogoff HA, Keates S, et al., Suppression of cancer relapse and metastasis by inhibiting cancer stemness, Proc Natl Acad Sci USA, 2015;112:1839-44.

202. Tan FH, Putoczki TL, Stylli SS, Luwor RB, The role of STAT3 signaling in mediating tumor resistance to cancer therapy, Curr Drug Targets, 2014;15:1341-53.

203. Shahda S, El-Rayes BF, O'Neil BH, et al., A phase Ib study of cancer stem cell (CSC) pathway inhibitor BBI-608 in combination with gemcitabine and nab-paclitaxel (nab-PTX) in patients (pts) with metastatic pancreatic ductal adenocarcinoma (mPDAC), I Clin Oncol, 2016;34(suppl 4S; abstr 284).

204. Bekaii-Saab TS, Mikhail S, Langleben A, et al., A phase Ib/Il study of BBI608 combined with weekly paclitaxel in advanced pancreatic cancer, J Clin Oncol, 2016;34(suppl 4S; abstr 196).

205. Hubbard JM, O'Neil BH, Jonker DJ, et al., Phase Ib study of cancer stem cell (CSC) pathway inhibitor BBI-608 administered in combination with FOLFIRI with and without bevacizumab (Bev) in patients (pts) with advanced colorectal cancer (CRC), I Clin Oncol, 2016;34(suppl 4S; abstr 569).

206. Cochrane CR, Szczepny A, Watkins DN, Cain JE, Hedgehog Signaling in the Maintenance of Cancer Stem Cells, Cancers, 2015;7:1554-85.

207. Panneerselvam J, Jin J, Shanker M, et al., IL-24 inhibits lung cancer cell migration and invasion by disrupting the SDF-1/CXCR4 signaling axis, PloS One, 2015;10:e0122439.

208. Graham NA, Graeber TG, Complexity of metastasis-associated SDF-1 ligand signaling in breast cancer stem cells, Proc Natl Acad SCiU S A, 2014;111:7503-4.

209. Gatti M, Pattarozzi A, Bajetto A, et al., Inhibition of CXCL12/CXCRA autocrine/paracrine loop reduces viability of human glioblastoma stem-like cells affecting self-renewal activity, Toxicology, 2013:314:209-20

210. Li L, Cole J, Margolin DA, Cancer stem cell and stromal microenvironment, The Ochsner Journal, 2013;13:109-18.

211. Kong F, Gao F, Li H, et al., CD47: a potential immunotherapy target for eliminating cancer cells, Clin Transl Oncol, 2016;18:1051-5.

212. Kaur S, Elkahloun AG, Singh SP, et al., A function-blocking CD47 antibody suppresses stem cell and EGF signaling in triplenegative breast cancer, Oncotarget, 2016;7:10133-52.

213. Theocharides AP, Jin L, Cheng PY, et al., Disruption of SIRPalpha signaling in macrophages eliminates human acute myeloid leukemia stem cells in xenografts, J Exp Med, 2012;209:1883-99.

214. Krampitz GW, George BM, Willingham SB, et al., Identification of tumorigenic cells and therapeutic targets in pancreatic neuroendocrine tumors, Proc Natl Acad Sci U S A, 2016;113:4464-9.

215. Todaro M, Perez Alea M, Scopelliti A, et al., IL-4-mediated drug resistance in colon cancer stem cells, Cell Cycle, 2008:7:309-13.

216. Yoo YD, Lee DH, Cha-Molstad H, et al., Glioma-derived cancer stem cells are hypersensitive to proteasomal inhibition, EMBO Reports, 2017;18:150-68.

217. Jachetti E, Caputo S, Mazzoleni S, et al., Tenascin-C Protects Cancer Stem-like Cells from Immune Surveillance by Arresting T-cell Activation, Cancer Res, 2015;75:2095-108.

218. Kakarala M, Wicha MS, Implications of the cancer stem-cell hypothesis for breast cancer prevention and therapy, $J$ Clin Oncol 2008:26:2813-20

219. Marjanovic ND, Weinberg RA, Chaffer $C L$, Cell plasticity and heterogeneity in cancer, Clin Chem, 2013;59:168-79

220. Singh SK, Clarke ID, Terasaki M, et al., Identification of a cance stem cell in human brain tumors, Cancer Res, 2003:63:5821-8.

221. He J, Liu Y, Zhu T, et al., CD90 is identified as a candidate marker for cancer stem cells in primary high-grade gliomas using tissue microarrays, Mol Cell Proteomics, 2012;11:M111.010744.

222. Ginestier $\mathrm{C}$, Hur MH, Charafe-Jauffret $\mathrm{E}$, et al., $\mathrm{ALDH} 1$ is a marker of normal and malignant human mammary stem cells and a predictor of poor clinical outcome, Cell Stem Cell, 2007;1:555-67.

223. Vaiopoulos AG, Kostakis ID, Koutsilieris M, Papavassiliou AG, Colorectal cancer stem cells, Stem Cells, 2012;30:363-71.

224. Cherciu I, Barbalan A, Pirici D, et al., Stem cells, colorectal cancer and cancer stem cell markers correlations, Curr Health SCi J 2014;40:153-61

225. Dalerba P, Dylla SJ, Park IK, et al., Phenotypic characterization of human colorectal cancer stem cells, Proc Natl Acad Sci U S A, 2007;104:10158-63

226. Huang EH, Hynes MJ, Zhang T, et al., Aldehyde dehydrogenase 1 is a marker for normal and malignant human colonic stem cells (SC) and tracks SC overpopulation during colon tumorigenesis, Cancer Res, 2009;69:3382-9.

227. Rutella S, Bonanno G, Procoli A, et al., Cells with characteristics of cancer stem/progenitor cells express the CD133 antigen in human endometrial tumors, Clin Cancer Res, 2009:15:4299-311.

228. Takaishi S, Okumura T, Tu S, et al., Identification of gastric cancer stem cells using the cell surface marker CD44, Stem Cells, 2009;27:1006-20.

229. Han J, Fujisawa T, Husain SR, Puri RK, Identification and characterization of cancer stem cells in human head and neck squamous cell carcinoma, BMC Cancer, 2014:14:173.

230. Majeti R, Chao MP, Alizadeh AA, et al., CD47 is an adverse prognostic factor and therapeutic antibody target on human acute myeloid leukemia stem cells, Cell, 2009;138:286-99.

231. van Rhenen A, van Dongen GA, Kelder A, et al., The novel AML stem cell associated antigen CLL-1 aids in discrimination between normal and leukemic stem cells, Blood, 2007;110:2659-66.

232. Hosen N, Park CY, Tatsumi N, et al., CD96 is a leukemic stem cellspecific marker in human acute myeloid leukemia, Proc Natl Acad SCIU S A, 2007:104:11008-13

233. Jan M, Chao MP, Cha AC, et al., Prospective separation of normal and leukemic stem cells based on differential expression of TIM3, a human acute myeloid leukemia stem cell marker, Proc Natl Acad Sci U S A, 2011;108:5009-14.

234. Saito Y, Kitamura H, Hijikata A, et al., Identification of therapeutic targets for quiescent, chemotherapy-resistant human leukemia stem cells, Sci Trans/ Med, 2010;2:17ra9.

235. Yamashita T, Wang XW, Cancer stem cells in the development of liver cancer, I Clin Invest, 2013:123:1911-8.

236. Ma S, Chan KW, Lee TK, et al., Aldehyde dehydrogenase discriminates the CD133 liver cancer stem cell populations, $M O$ Cancer Res, 2008;6:1146-53

237. Alamgeer M, Peacock CD, Matsui W, et al., Cancer stem cells in lung cancer: Evidence and controversies, Respirology, 2013;18:757-64.

238. Donnenberg VS, Landreneau RJ, Donnenberg AD, Tumorigenic stem and progenitor cells: implications for the therapeutic index of anti-cancer agents, J Control Release, 2007;122:385-91.

239. Bertolini G, Roz L, Perego P, et al., Highly tumorigenic lung cancer $\mathrm{CD} 133+$ cells display stem-like features and are spared by cisplatin treatment, Proc Natl Acad Sci U S A, 2009;106:16281-6.

240. Boonyaratanakornkit JB, Yue L, Strachan LR, et al., Selection of tumorigenic melanoma cells using ALDH, J Invest Dermatol, 2010;130:2799-808.

241. Zhang S, Balch C, Chan MW, et al., Identification and characterization of ovarian cancer-initiating cells from primary human tumors, Cancer Res, 2008:68:4311-20.

242. Li L, Hao X, Qin J, et al., Antibody against CD44S inhibits pancreatic tumor initiation and postradiation recurrence in mice, Gastroenterology, 2014;146:1108-18. 